\title{
Chicken Reproductive Performance in Ethiopia: Review
}

\author{
Sisay Fikru Mersha ${ }^{1, a}$, Ewonetu Kebede Senbeta ${ }^{1, b, *}$ \\ ${ }^{1}$ School of Animal and Range Sciences, Haramaya University, Ethiopia, P.O. Box 138, Dire Dawa, Ethiopia \\ *Corresponding author

A R T I C L E IN F O A B S T R A C T \\ Review Article \\ To improve the reproductive performance; several scholars conducted research in different parts of \\ Ethiopia on indigenous, crosses and exotic chickens. However, there were inconsistencies among \\ the various studies. This review was, therefore, conducted to assess the reproductive characteristics \\ of indigenous, exotic and their crosses. Under scavenging system, the indigenous chickens are \\ Received : 09/04/2020 \\ Accepted : 07/07/2020 \\ characterized by less clutch size (2.7-4.2 per year), good hatchability rate (59.6-93.2\%), higher \\ mortality rates (25.3-61.15), and reach sexual maturity at advanced age (19.6-26.8 weeks for male; \\ 19.7-34.05 weeks for female). The age at first mating and laying recorded for exotic and their \\ crossbreeds were nearly similar to those of indigenous chickens. The hatchability rate of crossbreed \\ chickens are varying from $54.7-78.7 \%$ and it is by far lower for exotic breeds. The exotic (18.83- \\ $53 \%$ ) and crossbreed $(9-40 \%)$ chickens are relatively better in survival rate than local chickens. \\ Overall, the local chickens are better for their hatchability and have reproduction performance than \\ exotic and crossbreed chickens. From this review, it is concluded that there is variation in chicken \\ reproductive performance of the same breed in different parts of the country.

\begin{tabular}{|c|c|}
\hline $\begin{array}{l}\text { Keywords: } \\
\text { Breed } \\
\text { Chickens } \\
\text { Ethiopia } \\
\text { Reproductive } \\
\text { Performances }\end{array}$ & $\begin{array}{l}53 \%) \text { and crossbreed }(9-40 \%) \text { chickens are relatively better in survival rate than local chickens. } \\
\text { Overall, the local chickens are better for their hatchability and have reproduction performance than } \\
\text { exotic and crossbreed chickens. From this review, it is concluded that there is variation in chicken } \\
\text { reproductive performance of the same breed in different parts of the country. }\end{array}$ \\
\hline
\end{tabular}

sisayfikru69@gmail.com (iD https://orcid.org/0000-0002-4119-9082

|b@ewonetu2011@gmail.com

https://orcid.org/0000-0002-3303-2194

(c) (1) (8) This work is licensed under Creative Commons Attribution 4.0 International License

\section{Introduction}

Reproduction is one of the most important aspects of poultry breeding (Abou-Elewa and Abdou, 2017) and it is characterized by parameters, such as, age at sexual maturity, fertility, hatchability, clutch size and clutch length (Addisu, 2013). Among reproduction traits, sexual maturity is paramount in terms of progress in poultry breeding (Chiemela et al., 2018). Age at sexual maturity refers to age at which the reproductive system achieves its complete development and it has long been considered as an important factor that determines fecundity trait and affects subsequent performance (Forment et al., 2009). In females, age at sexual maturity can be easily determined externally as age at which hens lay their first egg (Tandondjou et al., 2014). Early matured pullets laid their first egg before 136 days, while late pullets matured when they were 152 days of age or more (Amira, 2008). To some extent, late sexual development is demonstrated among the local chicken populations in comparison to different exotic pure breeds and hybrids (Chiemela et al., 2018) and one of the expressions of low productivity of local chicken ecotypes was also late maturity (Abera, 2000). As a consequence, many researchers have conducted crossbreeding for improvement of age at sexual maturity for native chickens in Africa (Chiemela et al., 2018).
In an attempt to increase poultry production; hatchability and high level of survivability cannot be over looked (Ajayi and Agaviezor, 2016). Hatchability is the percentage of fertile eggs that hatch (King'ori, 2011; Ndofor-Foleng et al., 2015). Hatchability determines levels of reproduction from the quantity of breeding stock within a phase of time (Obike et al., 2014; Ajayi and Agaviezor, 2016). As such, they vary across different breeds and diversified within same breed depending on genetic and environmental influence (Ajayi and Agaviezor, 2016). High hatchability of eggs of breeder stock and survivability of the chicks is necessary to produce large numbers of chickens (Ndofor-Foleng et al., 2015). Hatchability of $80 \%$ (of eggs set) from natural incubation is normal or a range of 75 to $80 \%$ is considered satisfactory (Sonaiya and Swan 2004). However, high hatchability can improve poultry production when there is good chick survival and good supply chain of day-old chicks (King'ori, 2011).

In addition, poultry breeders must consider total egg production rate as key traits in egg stocks (Schmidt and Figueiredo, 2005). Conversely, total egg production of a flock of hens is determined by the individual patterns of sequential laying, number of clutches and size of the clutches (Johnston and Gous, 2003). Laying sequence or 
clutch is defined as the number of eggs that are laid on consecutive days and separated from another by one or more pause days (Tumova et al., 2017). Egg production is characterized by the number of eggs in a clutch and the period between clutches, where oviposition fails to occur because of pause, which results in missing egg between clutches (Sakunthaladevi et al., 2011). Several scholars conducted research in different parts of Ethiopia on indigenous, crosses and exotic chicken characterization but there are inconsistencies among the various studies. This review was, therefore, carried out to assess the reproduction performance for indigenous, exotic and crossbreed chickens and need to publish in an organized form.

\section{Reproduction Performances}

\section{Age at Sexual Maturity}

In spite of genetic variation, the average age at sexual maturity reported in different parts of the country was different and it ranges from 19.6 to 26.8 weeks for male chickens (Table 1) and 19.7 to 34.05 weeks for female chickens (Table 2). This variation in age at sexual maturity may be due to the variation in environmental factors (temperature and nutrition) in different parts of the country. This supported by Guni et al. (2013), who observed variation both between and within districts with respect to age at first egg which is attributable to the genetic ecotype and non-genetic factors.

Table 1. Review of sexual maturity of male chickens in different parts of Ethiopia

\begin{tabular}{c|lll}
\hline Age at maturity(weeks) & \multicolumn{1}{c}{ Breed/s } & \multicolumn{1}{c}{ Study site } & \multicolumn{1}{c}{ Author/s } \\
26.0 & Indigenous & Central Tigray & Alem (2014) \\
25.9 & Cross & Central Tigray & Alem (2014) \\
24.6 & Exotic & Central Tigray & Alem (2014) \\
22.0 & Indigenous & Bure District & Fisseha et al. (2010) \\
24.3 & Indigenous & North west Ethiopia & Halima et al. (2007) \\
22.4 & Indigenous & North Wollo & Addisu et al. (2013) \\
19.6 & Indigenous & Sheka zone & Assefa et al. (2019) \\
24.0 & Koekoek & North Western Amhara & Sisay et al. (2017) \\
26.8 & BW & North Western Amhara & Sisay et al. (2017) \\
23.3 & Indigenous & Nole Kabba District (Wollega) & Matiwos et al. (2013) \\
22.5 & Indigenous & Metekel & Solomon et al. (2013) \\
23.5 & Indigenous & Gena Bossa District of Dawro Zone & Matawork et al. (2019) \\
20.0 & Indigenous & Fogera District & Bogale (2008) \\
19.6 & Indigenous & Mezhenger & Yadessa et al. (2017) \\
21.2 & Indigenous & Sheka & Yadessa et al. (2017) \\
\hline
\end{tabular}

BW= Bovan White

Table 2. Review of sexual maturity of female chickens in different parts of Ethiopia

\begin{tabular}{c|lll}
\hline Age at maturity(weeks) & \multicolumn{1}{|c}{ Breed/s } & \multicolumn{1}{c}{ Study site } & \multicolumn{1}{c}{ Author/s } \\
\hline 27.5 & Indigenous & Bure District & Fisseha et al. (2010) \\
22.3 & Indigenous & North west Ethiopia & Halima et al. (2007) \\
24.1 & Indigenous & Gena Bossa District (Dawro Zone) & Matawork et al. (2019) \\
25.2 & Indigenous & Central Tigray & Alem (2014) \\
25.4 & Cross & Central Tigray & Alem (2014) \\
30.3 & Exotic & Central Tigray & Alem (2014) \\
30.1 & Indigenous & Dale district & Mekonen (2007) \\
24.3 & Indigenous & Nole kabba district & Matiwos et al. (2013) \\
23.8 & Cross & Nole kabba district & Matiwos et al. (2013) \\
26.0 & Indigenous & North Wollo & Addisu et al. (2013) \\
21.6 & BB & North Western Amhara & Sisay et al. (2017) \\
25.2 & Koekoek & North Western Amhara & Sisay et al. (2017) \\
25.2 & BW & North Western Amhara & Sisay et al. (2017) \\
22.3 & Indigenous & Sheka zone & Assefa et al. (2019) \\
23.6 & Indigenous & Metekel & Solomon et al. (2013) \\
19.7 & Indigenous & Fogera District & Bogale (2008) \\
20.8 & Indigenous & Mezhenger & Yadessa et al. (2017) \\
20.6 & Indigenous & Sheka & Yadessa et al. (2017) \\
34.05 & Indigenous & Benchi-Maji & Yadessa et al. (2017) \\
22.18 & Indigenous & Boricha district, Sidama zone & Serkalem et al.(2019) \\
24.9 & Sasso & Boricha district, Sidama zone & Serkalem et al.(2019) \\
22.46 & Koekoek & Boricha district, Sidama zone & Serkalem et al.(2019) \\
& BB & Boricha district, Sidama zone & Serkalem et al.(2019) \\
\hline
\end{tabular}

$\mathrm{BB}=$ Bovance Brown, $\mathrm{BW}=$ Bovance White 
A slightly faster age of sexual maturity recorded for indigenous cockerel than pullet. Moreover, the age at first mating and laying recorded in Ethiopia for exotic and their crossbreed were nearly similar to those of indigenous. This contradicts the findings of Akhtar (2005), who reported that crossbred chickens attain sexual maturity earlier than their pure breeds. Almost similar age at first egg was reported for female indigenous chickens in Kenya (21.4weeks, Wambui et al., 2018) whereas the latter maturity age reported in Ghana (28-30 weeks, Dankwa et al., 2000), in Rwanda (30.2 weeks, Mahoro et al., 2017), in Tanzania (32.06 weeks, Guni et al., 2013), and in Botswana (27.3weeks, Moreki, 2010). Besides, Mwalusanya et al. (2002) reported that the age at first egg ranges between 6 and 8 months (25.71-34.3 weeks) for local chickens under village management conditions. The late age at first mating (7.02 month or 30.1 weeks) for indigenous male chickens in Tanzania was reported by Guni et al. (2013). The early maturity of indigenous chickens as compared to other some African countries indicated that the Ethiopian indigenous ecotypes are better in productivity. The known reasons for differences in the age at which chickens attain sexual maturity are in part, due to differences among breeds or ecotypes, strains within a breed and management system. This review showed the existence of variation in attainment of age at first mate and egg lay for indigenous, exotic and cross breeds chickens in different locations of the country. This agreed to the findings of Akhtar (2005) who argued that location had significant effect on sexual maturity.

\section{Hatchability Percentage}

As indicated in Table 3, many scientific scholars reported different hatchability performance for different chickens breeds in different parts of the country and it ranges between 59.6 and $93.2 \%$ for indigenous chickens whereas for the crossbreed it varies from 54.7 to $78.7 \%$. However, the hatchability percentages of eggs for exotic breeds are by far lower than the indigenous and crossbreed chickens. The hatchability rate for indigenous chickens in Ethiopia is within the range reported for family poultry in low income fooddeficit countries of Africa, which is 60-95\% (Gueye, 2003). However, the hatchability noted in Ethiopia for indigenous chickens is similar to results described in some other African countries, 50-100\% in Tanzania (Minga et al., 1989), 62-76\% in Kenya (Ndegwa et al., 2014), 60-90\% in Burkina Faso (Bourzat and Saunders, 1990), 60-95\% in Senegal (Gueye, 2003), 70.8-85.7\% in Uganda (Illango et al., 1999) and 70.1$78.3 \%$ in Nigeria (Sola-Oja, 2011). Besides, mean hatchability $(80.9 \%)$ for eggs of indigenous chickens observed in Ethiopia (Tadelle and Ogle, 1996) is higher than 69.7\% (Eugene, 2004) in Philippines, 78\% (Khalafalla, 2000) in Sudan and 74\% (Maphosa et al., 2004) in Zimbabwe despite the fact that it was lower than $90 \%$ in Sudan (Wilson, 1979), 82\% in Zimbabwe (Kusina et al., 2000), 83\% in Guinea (Mourad et al., 1997) and $84.9 \%$ in Uganda (Kirunda et al., 2010). While the normal hatchability (80\%) or a satisfactory hatchability ( 75 to $80 \%$ ) had also been reported among village chickens in other studies in other countries for natural incubation (Sonaiya and Swan, 2004).

Table 3. Review of hatchability in different parts of Ethiopia

\begin{tabular}{c|clll}
\hline Eggs set no. & Hatchability $(\%)$ & \multicolumn{1}{c}{ Breed } & \multicolumn{1}{c}{ Study site } & \multicolumn{1}{c}{ Author/s } \\
\hline 10.2 & 85.7 & Indigenous & Central Tigray & Alem (2014) \\
8.3 & 78.7 & Cross & Central Tigray & Alem (2014) \\
13.0 & 59.6 & Indigenous & Nebsie sar midir district & Melkamu and Andarge (2014) \\
11.3 & 82.7 & Indigenous & Nole kabba district & Matiwos et al. (2013) \\
9.5 & 44.4 & Exotic & Nole kabba district & Matiwos et al. (2013) \\
11.6 & 83.6 & Indigenous & Assosa zone & Alemayehu et al. (2015) \\
11.6 & 80.2 & Indigenous & Kamashi zone & Alemayehu et al. (2015) \\
11.8 & 83.9 & Indigenous & Mao-komo district & Alemayehu et al. (2015) \\
13.0 & 92.3 & Indigenous & South Gonder zone & Halima et al. (2007) \\
13.0 & 87.2 & Indigenous & West Gojam zone & Halima et al. (2007) \\
13.0 & 88.5 & Indigenous & Awi zone & Halima et al. (2007) \\
13.0 & 93.2 & Indigenous & East Gojam zone & Halima et al. (2007) \\
14.7 & 84.7 & Indigenous & Metekel zone & Solomon et al. (2013) \\
DNF & 77.5 & Indigenous & North western Amhara & Sisay et al. (2017) \\
DNF & 12.7 & BB & North western Amhara & Sisay et al. (2017) \\
DNF & 54.7 & Koekoek & North western Amhara & Sisay et al. (2017) \\
DNF & 34.0 & BW & North western Amhara & Sisay et al. (2017) \\
13.0 & 82.6 & Indigenous & Bure district & Moges et al. (2010) \\
9.8 & 89.0 & Indigenous & Dale district & Moges et al. (2010) \\
13.0 & 78.9 & Indigenous & Fogera district & Moges et al. (2010) \\
12.7 & 81.7 & Indigenous & Dawro zone & Matawork et al. (2019) \\
\hline
\end{tabular}

$\mathrm{DNF}=$ data is not found, $\mathrm{BB}=$ Bovance Brown, $\mathrm{BW}=$ Bovance White

The hatchability of exotic and their crosses were relatively lower than the pure line indigenous chickens (Table 3). The natural hatchability percent in Ethiopia under backyard management system is better than the hatchability revealed (63.1- 84.1\%) under backyard conditions (Farooq et al., 2000). This variability in hatchability might be raised from the genotype and husbandry practices given to chickens in different regions of the country. Moreover, several factors have been examined to affect hatchability and, among others, they include season of lay, disease, nutrition, age, egg quality, genetic factors, hygiene and incubation conditions (Kirunda et al., 2010; Nebiyu et al., 2013). This difference might be also due to disparity of feed and water given to the broody hen at incubation time. 


\section{Clutch Size and Length}

Despite their breed, the overall number of clutch size observed in different parts of the country under Smallholders' is various and it ranges between 2.7 and 4.3 per year (Table 4). This was almost similar to values reported in Ghana (3-4; Aboe et al., 2006), in Kenya (3-4; Olwande et al., 2009), in Uganda (2.5-3.0; Kyarisiima et al., 2004), in Burkina Faso (2.7-3.0; Bourzat and Saunder, 1990) and in other developing countries (2-3 clutches; Moges et al., 2010). Moreover, different average numbers of clutch sizes were observed per hen per year in some other African countries such as 3.7 in Ghana (Awuni, 2005), 3.1 in Uganda (Ssewannyana et al., 2004), 2.6 in Rwanda (Mahoro et al., 2017), 3.2 in Gambia (Kitalyi and Mayer, 1998), 3.78 in Guinea (Mourad et al., 1997), 3.3 in Tanzania (Guni et al., 2013) and 4 in Nigeria (Wambui et al., 2018). However, higher mean number of clutches per year was reported in Sudan (4.5; Wilson, 1979) and in Ethiopia (4.6; Mengesha et al., 2008). The observed differences among countries with respect to number of clutches per year might be related to the practices taken by the farmers to break broodiness. This concurred to Nebiyu et al. (2013), who reported that farmers break broodiness by taking the hen to other places for few days, piercing the nostrils with feathers, hanging the hen upside down for about 2 to 3 hours per day for consecutive 3 days so as to increase the number of clutches. The number of eggs laid per clutch in Ethiopia is ranged from 10.10 to 21.0 which is higher than eggs per clutch reported in Senegal (8-10; Missohou et al., 2002), Uganda (10-14; Ssewannyana et al., 2004), in Kenya (12-20; Olwande et al., 2009), Burkina Faso (12-18; Bourzat and Saunders, 1990), Tanzania (620; Minga et al.,1989) and in other developing countries (9-19 eggs; Kingori et al., 2010; Moges et al., 2010). The observed egg production per hen per clutch was fallen within 6-26 which noted in the country by central statistical agency (CSA, 2003). However, this value was higher than 10-14 average egg production per clutch per hen reported in Uganda (Ssewannyana et al., 2004) and in Sudan (Khalafalla, 2000) for the village chickens.

Table 4. Review of clutch size and clutch length in different parts of Ethiopia

\begin{tabular}{c|clll}
\hline Clutch size & Clutch Length (days) & Eggs/clutch & \multicolumn{1}{c}{ Breed } & \multicolumn{1}{c}{ Author/s } \\
\hline 3.0 & 16.0 & $12-13$ & Indigenous & Bogale (2008) \\
3.0 & 25.3 & 12.78 & Indigenous & Matawork et al. (2019) \\
3.2 & 21.6 & 13.60 & Indigenous & Alem (2014) \\
3.1 & 31.6 & 27.40 & Cross & Alem (2014) \\
3.2 & 44.4 & 41.80 & Exotic (RIR) & Alem (2014) \\
2.7 & 27.9 & 10.10 & Indigenous & Alemayehu et al. (2015) \\
3.8 & 26.2 & 14.60 & Indigenous & Moges et al. (2010) \\
3.9 & 27.7 & 14.40 & Indigenous & Yadessa et al. (2017) \\
3.8 & 26.0 & 13.30 & Indigenous & Nebiyu et al. (2013) \\
3.7 & 24.7 & 14.20 & Indigenous & Letebrhan et al. (2015) \\
3.6 & 20.0 & 12.30 & Indigenous & Tadele et al. (2018) \\
4.2 & 25.9 & 14.80 & Indigenous & Zereu and Lijalem (2016) \\
4.3 & 31.9 & 31.24 & BB & Sisay et al. (2017) \\
3.9 & 34.7 & 34.50 & Koekoek & Sisay et al. (2017) \\
3.9 & 42.5 & 40.10 & BW & Sisay et al. (2017) \\
4.0 & 12.0 & 21.00 & Indigenous & CSA (2017/18) \\
4.0 & 38.0 & 45.00 & Cross & CSA (2017/18) \\
DNF & 133.0 & 169.00 & Exotic & CSA (2017/18) \\
DNF & DNF & 13.30 & Indigenous & Serkalem et al.(2019) \\
DNF & DNF & 25.10 & Sasso & Serkalem et al.(2019) \\
DNF & DNF & 25.00 & BB & Serkalem et al.(2019) \\
DNF & DNF & 26.20 & Koekoek & Serkalem et al.(2019)
\end{tabular}

$\mathrm{DNF}=$ data is not found, $\mathrm{BB}=$ Bovance Brown, $\mathrm{BW}=$ Bovance White

Besides, average of 12.5 eggs per clutch was reported in Nigeria (Wambui et al., 2018). The mean value of clutch length for indigenous chicken was varying from 12 to 27.7 days (Table 4). In various parts of the country, many scholars reported different clutch length for indigenous chicken, 22.54 (Brhane et al., 2017), 26.2 (Mekonnen, 2007), 26 (Nebiyu et al., 2013) and 15 to 28 days (Alem, 2014). On average, 26 days of clutch length was reported in southern parts of the country, which is higher than the values (17.8 days) reported in Tanzania (Guni et al., 2013). The observed differences between countries with respect to number of clutches per year, eggs per clutch and clutch length might be due to both genetic and environmental differences. Moreover, this difference might be due to differences in management (health care, feed type and feeding frequency) and weather conditions in various agroecologies of the country.

\section{Mortality Rate}

Indigenous chickens are known by their desirable characters such as resistance to diseases and adapted to their environment (Abdelqader et al., 2007; Nebiyu et al., 2013). However, the figures in Table 5 demonstrated higher mortality rates (25.3-61.15) for the Ethiopian indigenous chicken kept under backyard management conditions than crossbreed and exotic managed under similar conditions. Figures in Table 5 illustrated as the crossbreed (9-40\%) chickens are relatively better in survival rate than indigenous (25.3-61.15) and exotic breed (18.83-53\%). This might be due to resistance development in crossbreed chickens than the pure breed. Likewise, the higher average mortality for indigenous chickens were reported in some African countries (50.25\% in Nigeria), (56.5\% in Senegal), (62.5\% in Ghana), (61.5 in Ethiopia), (53.75\% in Cote decIvoire), (74\% in Uganda), (40-60\% in Kenya), (30.2\% in Tanzania) 
(Mourad et al., 1997; Sonaiya et al., 1999; Kingori et al., 2010; Guni et al., 2013). Besides, Solomon (2004) reported higher mortality percentage $(24 \%)$ for indigenous chickens kept under an intensive management system. Chicken mortalities in Ethiopia due to diseases are estimated to range from 20 to $50 \%$, but it may rise as high as $80 \%$ during epidemics (Tadelle and Ogle, 2001). Similarly, Sonaiya and Swan (2004) reported 50 to $100 \%$ mortality in Africa due to Newcastle disease whereas Moreki (2010) reported higher rate of chicken mortality due to mismanagement, predator and diseases in the continent. This variation in mortality rate of chickens in different parts of Ethiopia and other African countries could be due to the variation in breed type or ecotype, agro-ecological differences, chickens health management, prevalence of predators, density of chickens kept, and season of the year. Thus, improvement in managerial practices is necessary to reduce mortality since it is an important indicator for poor welfare (LayWel, 2006).

Table 5. Review of mortality rate from hatching to maturity age under backyard management system

\begin{tabular}{c|ll}
\hline Mortality $(\%)$ & \multicolumn{1}{c}{ Breed/s } & \multicolumn{1}{c}{ Author/s } \\
\hline 59.9 & Local breed (Jarso ecotype) & Tadelle and Ogle (2001); Reta (2009) \\
26.6 & Local breed (Konso ecotype) & Reta (2009) \\
37.2 & Local breed (Tepi ecotype) & Reta (2009) \\
25.3 & Local breed (Horro ecotype) & Reta (2009) \\
27.4 & Local breed (Tilili ecotype) & Reta (2009) \\
60.0 & Local breed & Tadelle and Ogle (2001); Reta (2009) \\
34.2 & Local breed & Alem (2014) \\
61.15 & Local breed & Matawork et al. (2019) \\
53.74 & Local breed & Brhane et al. (2017) \\
48.7 & Local breed & Tadelle (2000) \\
44.2 & Local breed & Abraham and Yayneshet (2010) \\
19.0 & Crossbreed (Local and Fayoumi) & Fassill et al. (2010) \\
18.0 & Crossbreed (Local and RIR) & Fassill et al. (2010) \\
9.0 & Crossbreed (Local and Fayoumi) & Fassill et al. (2010) \\
40.0 & Crossbreed (Local and RIR) & Fassill et al. (2010) \\
36.3 & Crossbreed & Alem (2014) \\
38.12 & Exotic breed & Brhane et al.(2017) \\
48.8 & White Leghorn & Addis and Malede (2014) \\
53.0 & Yarkon & Addis and Malede (2014) \\
44.5 & Fayoumi & Ewonetu (2017) \\
18.83 & White Leghorn & Ewonetu (2017) \\
17.50 & Bovans White & Kumar et al.(2014) \\
33.3 & Rhode Island Red & Addis and Malede (2014) \\
$18.6-25.4$ & Rhode Island Red & Reta et al. (2012) \\
18.9 & Rhode Island Red & Kumar et al.(2014) \\
\hline & &
\end{tabular}

\section{Conclusion}

This review indicated as variations exist in chickens reproductive performances in different areas of Ethiopia. This variation explained by many scholars in relation to chickens breed, available feed, agro-ecology, disease and other environmental factors. The mortality rate reported in Ethiopia is higher (25.3-61.15\%) than the observed mortality in other African countries. There is some evidence that there is a large amount of genetic discrepancy in chicken reproduction performances in Ethiopia and this indicates the existence of divergent subpopulations within the chicken population that gives room for genetic improvement between and within subpopulations. Finally, this review draws the following recommendations:

- The reproductive performances of chickens in Ethiopia is almost similar to other African countries.

- Attention should be given to improve the chicken survival rate or decrease mortality

- There was few known report of on-farm research experiment on the reproductive performances of the indigenous chickens. Thus, indigenous chickens should be evaluated under intensive and good management conditions in order to have fairly accurate figures on their reproductive performances.

\section{Acknowledgements}

The authors are grateful for the other publishers who freely accessed their material to review and compile this manuscript.

\section{References}

Abdelqader A, Wollny CBA, Gauly M. 2007. Characterization of local chicken production system and potential under different level of management practice in Jordan. Journal of Tropical animal health and production, 39: 155-164.

Abera M. 2000. Comparative studies on performance and physiological responses of Ethiopian indigenous chicken and their F1 crosses to long-term heat stress. Ph.D Thesis. MartinLuther University, Halle-Wittenberg, Berlin. pp4-5.

Aboe PAT, Boa-Amponsem K, Okantah SA, Butler EA, Dorward PT, Bryant MJ. 2006. Free-range village chickens on the Accra Plains, Ghana: Their husbandry and productivity. Tropical Animal Health and Production 38: 235-248.

Abou-Elewa EM, Enab AA, Abdou FH. 2017. Sexual Maturity of Male Chickens According To Early Response of Semen Collection. IOSR Journal of Agriculture and Veterinary Science, 10 (7): 58-63. 
Abraham L, Yayneshet T. 2010. Performance of exotic and indigenous poultry breeds managed by smallholder farmers in northern Ethiopia. Livestock Research for Rural Development, 22(7): 29.

Addis G, Malede B. 2014. Effect of gene segregation on existing performance of chicken ecotypes in Ethiopia. Middle-East Journal of Scientific Research, 21: 675-680.

Addisu H, Hailu M, Zewdu W. 2013. Review: Indigenous chickens production system and breeding practice in North Wollo, Amhara region, Ethiopia. Scholarly Journal of Agricultural Science, 3: 433-444.

Addisu H. 2013. Phenotypic characterization of indigenous chicken ecotypes in Northwollo, Amhara Regional State, Ethiopia. Master's thesis, pp87.

Adetayo AS, Babafunso SE. 2001. Comparison of the performance of Nigerian indigenous chickens from three agro-ecological zones. Livestock Research for Rural Development, 13(2): 1-6.

Ajayi FO, Agaviezor BO. 2016. Fertility and Hatchability Performance of Pure and Crossbred Indigenous Chicken Strains in the High Rainforest Zone of Nigeria. International Journal of Livestock Production, 7(12), pp141-144.

Akhtar MUZ. 2005. Egg production performance of different breed/breed combinations of chicken in a semi-scavenging system under PLDP. An MSc. Thesis submitted to the Department of Animal Breeding and Genetics, Danish Institute of Agricultural Sciences, Denmark.143.

Alem T. 2014. Production and Reproduction Performance of Rural Poultry in Lowland and Midland Agro-Ecological Zones of Central Tigray, Northern Ethiopia. British Journal of Poultry Sciences, 3: 06-14.

Alemayehu A, Yilma T, Shibeshi Z, Workneh T, 2015. Village Chickens Production Systems in Selected Areas of Benishangul-Gumuz, Western Ethiopia. Asian Journal of Poultry Science, 9: 123-132.

Amira EE. 2008. The Relationship between Age at Sexual Maturity and Some Productive Traits in Local Chickens Strain. Egypt Poultry Science, 28 (4): 1253-1263.

Assefa M, Amanuel B, Tekalign T. 2019. Characterization of Village Chicken Production and Husbandry Practices in Dedo District, Jimma Zone, South West Ethiopia. International Journal of Veterinary Science and Agriculture Research, 1(1): 13-24.

Awuni JA. 2005. Strategies for the improvement of rural chicken production in Ghana. www.naweb.iaea.org/nafa/aph/public/ 4-strategies-awuni.pdf (Accessed on $28^{\text {th }}$ March, 2020).

Bogale K. 2008. In situ characterization of local chickens ecotype for functional traits and production system in Fogera district, Amahara regional state. M.Sc. Thesis submitted to the department of animal science school of graduate studies, Haramaya University, pp: 107.

Bourzat D, Saunders M. 1990. Improvement of traditional methods of poultry production in Burkina Faso. In Proc CTA seminar, $3^{\text {rd }}$ International Symposium on poultry production in hot climates, Hameln, Germany, 12 June 1987.

Brhane G, Hailu M, Tikabo G. 2017. On-Farm Productive and Reproductive Performance of Local, Exotic and Crossbred Chickens in Southern Tigray, North Ethiopia. Journal of Biology, Agriculture and Healthcare, 7(13): 42-50.

Chiemela PN, Jun HL, Egbu CF, Seung-Hwan L. 2018. Review on the Genetic Potential of Nigerian Local Chickens. Journal of Animal Breeding and Genomics, 2(4): 199-211.

CSA. 2003. Central Statistical Authority, Statistical report on livestock and farm implements, part 4, Addis Ababa, Ethiopia.

CSA. 2017/18. Central Statistical Authority, Agricultural sample survey. Report on livestock and livestock characteristics volume II. p20-22.

Dankwa D, Nelson FS, Mzamo KB, Oddoye EOK. 2000. A survey of rural poultry management in West Mamprusi and the Ga Districts of Ghana. Ghanaian Journal of Agricultural Science, 33(1): 71-77.
Eugene F. 2004. A longitudinal analysis of chicken production systems of smallholder farmers in Leyte, Philippines. Leyte State University, Leyte, The Philippines.

Ewonetu Kebede Senbeta. 2017. Growth Performance and Rearing Costs of Fayoumi and White Leghorn Chicken Breeds. East African Journal of Sciences, 11 (1): 37-42.

Farooq M, Shoukat K, Asrar M, Shah M, Durrani FR, Asghar A, Faisal S. 2000. Impact of Female Livestock Extension Workers (FLEWs) on rural household chicken production in Mardan division. Livestock Research for Rural Development, 12 (4): 1-6.

Fassill B, Ådnøy T, Gjøen HM, Kathle J, Girma A. 2010. Production Performance of Dual Purpose Crosses of Two Indigenous with Two Exotic Chicken Breeds in Sub-tropical Environment. International Journal of Poultry Science, 9: 702-710.

Fisseha M, Abera M, Tadelle D. 2010. Assessment of village chickens production system and evaluation of the productive and reproductive performance of local chickens ecotype in Bure district, North West Ethiopia. African Journal of Agricultural Research, 5: 1739-1748.

Forment P, Ouste C, Pelletier R, Brillard JP. 2009. Rôle de L'AMP-activated protein kinase dans l'activitē des cellules de Sertoli de coq immature (Gallus domesticus).Huitimes Journēes de la recherché avicole, St Malo., pp25-26.

Gueye EF. 2003. Poverty alleviation, food security and the wellbeing of the human population through family poultry in low income food-deficit countries. Senegalese Institute of Agricultural research (ISRA), B.P.2057, Dakar-hann, Senegal.

Guni FS, Katule AM, Mwakilembe PAA. 2013. Characterization of local chickens in selected districts of the Southern Highlands of Tanzania: II. Production and Morphometric traits. Livestock Research for Rural Development, 25 (11).

Halima H, Neser F, Van Marle-Koster E, De Kock A. 2007. Village-based indigenous chickens production system in north-west Ethiopia. Journal of Tropical Animal Health and Production, 39: 189-197.

Illango J, Etoori A, Olupot H, Mabonga J. 1999 Rural Poultry Production in two agro-ecological zones in Uganda, http://www.iaea.org/nafa/d3/public/12-rural-illango.pdf, Last accessed July 2020.

Johnston SA, Gous RM. 2003. An improved mathematical model of the ovulatory cycle of the laying hen. British Poultry Science, 44: 752-760.

Khalafalla SWH. 2000. Village poultry production in Sudan. Department of micro biology, Faculty of veterinary science, University of Khartoum, Khartoum, North Sudan.

Kingori AM, Wachira AM, Tuitoek JK. 2010. Indigenous chicken production in Kenya: A review. International Journal of Poultry Science, 9(4):309-316.

Kirunda H, Muwereza N, Kasaija DP, Kerfua DS, Jumanyol K. 2010. Infectious and non-infectious factors affecting hatchability in indigenous chickens in Eastern Uganda. Africa Journal of Animal and Biomedical Sciences, 5(3):51-59.

Kitalyi AJ, Mayer A. 1998. Village chicken production systems in rural Africa household food security and gender issues. FAO, Rome.

Kumar N, Zinabu NB, Abebe MS, Habtamu T. 2014. Comparative Study of Performance of Rhode Island Red and Bovans White under Intensive Management in Mekelle, Ethiopia. International Journal of Livestock Research, 4(2): 2277-1964.

Kusina JF, Kusina NT, Mhlanga J. 2000. Poultry production in Mashonaland Central Province: The role and opportunities for women. Integrated Crop-Livestock Production in Smallholder Farming Systems in Zimbabwe. Proceedings of a Review Workshop, Harare, Zimbabwe 10-13 January 2000, pp247-264.

Kyarisiima C, Kugonza DR, Twesigye CK. 2004. The potential role of Ugandan indigenous chicken in poverty alleviation. The Uganda Journal, 50: 85-90. 
LayWel. 2006. Welfare implications of changes in production systems for laying hens: a European project. (In particular Work Package 1: Laying hen welfare definitions and indicators. Available from: http://www.laywel.eu.

Letebrhan G, Aberra M, Sandip B, Gebremedhn B. 2015. Characterization of Village Chicken Production System under Traditional Management System in Gantaafeshum District of Eastern Tigray, Ethiopia. Livestock Research for Rural Development, 27(9).

Mahoro J, Muasya TK, Mbuza F, Habimana R, Kahi AK. 2017. Characterization of indigenous chicken production systems in Rwanda. Poultry Science, 96(12): 4245-4252.

Maphosa T, Kusina J, Kusina NT, Makuza S, Sibanda S. 2004. A monitoring study comparing production of village chickens between communal (Nharira) and small-scale commercial (Lancashire) farming areas in Zimbabwe. Livestock Research for Rural Development, 16(7).

Matawork M, Meseret M, Samuel T. 2019. Productive and reproductive performance of indigenous chickenss in Gena Bossa District of Dawro Zone, Ethiopia. International Journal of Livestock Production, 10(1): 24-32.

Matiwos H, Negassi A, Solomon D. 2013. Production performance of local and exotic breeds of chickens at rural household level in Nole Kabba Woreda, Western Wollega, Ethiopia. African Journal of Agricultural Research, 8(11):1014-1021.

Mekonnen G. 2007. Characterization of the small holder poultry production and marketing system of dale, wonsho and loka abaya weredas of snnprs. MSc Thesis. Hawassa University, p45.

Melkamu BY, Andarge Z. 2014. Performance Evaluation of Local Chicken At Enebsie Sar Midir Woreda, Eastern Gojjam, Ethiopia. Global Journal of Agriculture and Food Sciences Research, 1(2):1-8.

Mengesha M, Tamir B, Dessie T, 2008. Socio-economical contribution and labor allocation of village chicken production in Jamma district, South Wollo, Ethiopia. Livestock Research for Rural Development, 20(10).

Minga UM, Katule A, Maeda T, Musasa J. 1989. Potential and problems of the traditional chicken industry in Tanzania. In: proceedings of the $7^{\text {th }}$ Tanzania Veterinary Association Scientific Conference, pp207-215.

Moges F, Azage T, Dessie T. 2010. Indigenous chicken production and marketing systems in Ethiopia. Characteristics and opportunities for market-oriented development. IPMS (Improving Productivity and Market Success) of Ethiopian Farmers Project Working Paper 24. Nairobi, Kenya, ILRI, pp5-28.

Moreki JC. 2010. Village poultry production in Serowe-Palapye sub-district of Botswana. Jrl. Livestock Research for Rural Development. 22:5-8.

Mourad M, Bah AS, Gbanamou G. 1997. Productivity and mortality of local Poultry in the plateau of Sankaran Faranah, Guinea, 1993-1994. Revue d Elevage et de Medecine Veterinaire des Pays Tropicaux, 50: 343-349.

Mwalusanya NA, Katule AM, Mutayoba SK, Mtambo MMA, Olsen JE, Minga UM. 2002. Productivity of local chickens under village management conditions. Tropical Animal Health and Production, 34: 405-416.

Ndegwa JM, Mead R, Norrish P, Shephered DD, Kimani CW, Wachira AM, Siamba DN. 2014. Investigating eggs hatchability in indigenous chicken system with smallholder farms in Kenya in a participatory research using analysis of variation. Journal of Applied Biosciences, 80:7000-7013.

Ndofor-Foleng HM, Oleforuh-Okoleh V, MusongongGA, Ohageni J, Duru UE. 2015. Evaluation of growth and reproductive traits of Nigerian local chicken and exotic chicken. Indian Journal of Animal Research, 49(2): 155-160.

Nebiyu Y, Berhan T, Kelay B. 2013. Characterization of village chicken production performance under scavenging system in Halaba district of southern Ethiopia thiopian, Veterinary Journal, 17(1): 69-80.
Obike OM, Nwachukwu EN, Ukewulonu IE. 2014. Effect of strain and associations of some fertility and hatchability traits of indigenous guinea fowls raised in the rain-forest zone of South-East Nigeria. Global Journal of Animal Breeding and Genetics, 2(7): 098-102.

Olwande PO, Ogara WO, Okuthe SO, Muchemi G, Okoth E, Odindo MO, Adhiambo RF. 2009. Assessing the productivity of indigenous chickens in an extensive management system in Southern Nyanza, Kenya. International journal of Poultry Science, 9(4): 309-316.

Reta D, Negussie D, Alemu Y. 2012. Comparative production performance of two exotic chicken breeds under two different feed regimes in three agro-ecologies of central Oromia, Ethiopia - a step forward for distribution or contract rearing of day old exotic chicks under rural setting. Livestock Research for Rural Development 24 (9).

Reta D. 2009. Understanding the role of indigenous chickens during the long walk to food security in Ethiopia. Livestock Research for Rural Development, 21(8).

Sakunthaladevi K, Ramesh GB, Gnana PM, Qudratullahi S, Rajasekhar RA. 2011. Genetic analysis of production, reproduction and clutch traits in Japanese Quails. Tamilnadu Journal of Veterinary and Animal Sciences, 7 (3): 126-132.

Schmidt GS, Figueiredo EAP. 2005. Selection for Reproductive Traits in White Egg Stock Using Independent Culling Levels. Brazilian Journal of Poultry Science, 7(4): 231 - 235.

Serkalem A, Aberra M, Sandip B. 2019. Egg Production and Egg Quality Traits of Local and Exotic Chickens Breeds Reared in Two Agroecologies under Traditional Management System. Research Journal of Food and Nutrition, 3(1): 11-17.

Sisay T, Kefeyalew A, Zewdu W. 2017. Population Dynamics and Performance of Exotic versus Indigenous Chickens Population in the Selected Districts of North Western Amhara, Ethiopia. Tropical Drylands, 1(2): 90-99.

Sola-Oja FE, Ayorinde KL. 2011. Evaluation of Reproductive Performance and Egg Quality traits in Progenies of Dominant Black Strain Crossed with Fulani Ecotype Chicken. Journal of Agricultural Science, 3(1): 258-265.

Solomon D. 2004. Egg production performance of local and White Leghorn hens under intensive and rural household conditions in Ethiopia. Livestock Research for Rural Development, 16: 491-501.

Solomon Z, Binyam K, Bilatu A, Ferede A. 2013. Village chickens production systems in Metekel zone, Northwest Ethiopia. Wudpecker Journal of Agricultural Research, 2: 256-262.

Sonaiya EB, Branckaert RDS, Gueye EF. 1999. Research and development options for family poultry. First INFPD/FAO electronic conference on family poultry, $7^{\text {th }}$ December 1998$5^{\text {th }}$ March 1999, Berlin, Germany.

Sonaiya EB, Swan SEJ. 2004. Incubation and Hatching, SmallScale Poultry Production Technical Guide, Animal Production and Health, Food and Agriculture Organization of the United Nations, Rome.

Ssewannyana E, Ssali A, Kasadha T, Dhikusooka M, Kasoma, Kalema, P. 2004. Characterization of indigenous chickens of Uganda, Kampala, Uganda. Uganda Journal of Agricultural Sciences, 8:137-141.

Tadele A, Melesse A, Taye M. 2018. Phenotypic and morphological characterizations of Indigenous chicken populations in Kaffa Zone, South Western Ethiopia. Animal Husbandry, Dairy and Veterinary Science, 2(1): 1-9.

Tadelle D, Alemu Y, Peters KJ. 2000. Indigenous Chickens in Ethiopia, Genetic Potential and Attempts at Improvement. World's Poultry Science Journal, 56: 45-54.

Tadelle D, Ogle B. 1996. A survey of village poultry production in the central highlands of Ethiopia. (M.Sc. Thesis) Swedish University of Agricultural Science, pp22. www.fao.org/Ag/AGAInfo/resources/.../frg/.../tadelle.htm, Last accessed October 2019. 
Tadelle D, Ogle B. 2001. Village poultry production systems in the central highlands of Ethiopia. Tropical Animal Health and Production, 33: 521-537.

Tumova E, Uhlirova L, Tuma R, Chodova D, Machal L. 2017. Age related changes in laying pattern and egg weight of different laying hen genotypes. Animal Reproduction Science, 183: 21-26.

Wambui CC, Njoroge EK, Wasike CB. 2018. Characterization of physical egg qualities in indigenous chicken under free range system of production in Western Kenya. Livestock Research for Rural Development, 30 (7).
Wilson RT. 1979. Studies on the livestock of Southern Sudan. Production of poultry under simulated traditional conditions. Tropical Animal Health Production, 11: 143-150.

Yadessa ET, Bogale D, Mengistu A, Aleme G, Shiferawu M, Esatu SW, Amare A. 2017. Characterization of smallholder poultry production system in Meshenger, Sheka and BenchiMaji zones of south western Ethiopia. Research Journal of Agricultural Science Research, 5(1): 2360-7874.

Zereu G, Lijalem T. 2016. Production and reproduction performance of local chickens breeds and their marketing practices in Wolaita Zone, Southern Ethiopia. African Journal of Agricultural Research, 11(17): 1531-1537. 